\title{
INTERNAL AUDIT TECHNIQUE AT RETAIL ENTERPRISES
}

\author{
Barysheva S.K., Byktubaeva A.S., Shalabayev O. \\ Accounting and Auditing «Turan» Universiti \\ Olgasshalobaev14@gmail.com \\ ORCID 0000-0001-5399-6794
}

Key words:

control, audit, internal audit, efficiency.
One of the currently significant, as well as promising and effective types of control over the financial and economic activities of economic entities in market conditions is an independent audit control, which is carried out by auditors, audit organizations operating on a commercial contract basis at the expense of the client (audited entity).

The organization should create such a control system that would not only guarantee the absence of deviations, errors and inefficiencies in work, but would help to identify and eliminate them in a timely manner, contributing to increased efficiency. After all, the resources allocated by the company to create excess control could be used to achieve other goals and objectives. However, even a well-built and organized internal control system needs to assess its effectiveness both in terms of achieving the set goals and in terms of efficiency. The internal audit serves this purpose.

For timely and more effective internal control, organizations use internal audit. The tasks of internal audit include the creation of an internal control system necessary to exercise the competence, rights and responsibility of management bodies and officials, as well as a clear system of economic responsibility of officials and specialists of the organization. The internal audit provides analytical information to the top management of the organization about its financial and economic activities, increases the efficiency of the internal control system and confirms the reliability of the reports of its separate structural divisions. Thus, the functioning of large companies in a business environment objectively led to the creation of an internal audit service in the management apparatus. The international experience of US and Western European joint stock companies shows that internal audit is becoming an integral part of effective corporate governance. The internal audit is an element of the internal control system, an independent and objective activity related to risk management, assessment and confirmation of the reliability of financial statements, with verification and assessment of the company's activities as a whole in its interests and for various users.

After analyzing the known approaches to the formation of the general plan and audit program of the company, including audit tasks, we came to the conclusion that audit tasks are incompatible with the tasks of internal audit, since the purpose of the audit is to prevent inefficient use of resources, to identify and prevent abuse. The revision is retrospective-oriented, i.e. on events that have already taken place and their consequences. Thus, we have developed the following procedure for organizing internal audit planning in an organization where there is an internal audit service.

In addition to the control and analytical function, the internal audit system can perform information and consulting. In this case, it means consulting employees of all structural divisions and heads of the organization on issues within the competence of internal auditors. For example, consulting in the field of finance, economics, taxation, etc.

Thus, depending on the function performed, the internal audit can be in different relationships with the internal control system at the enterprise. If the internal audit in an organization performs control functions, then in this case it will clearly be part of the internal control system in an economic entity.

\section{МЕТОДИКА ВНУТРЕННЕГО АУДИТА НА ПРЕДПРИЯТИЯХ РОЗНИЧНОЙ ТОРГОВЛИ}

\section{Барышева С.К., Биктеубаева А.С., Шалабаев О.}

\author{
Учет и аудит, Университета «Туран»
}

\section{Ключові слова:}

контроль, аудит, внутренний аудит, эффективность.
Одним из значимых в настоящее время, а также перспективных и эффективных видов контроля финансово-хозяйственной деятельности экономических субъектов в условиях рынка является независимый контроль аудит, который проводится аудиторами, аудиторскими 
организациями, осуществляющими свою деятельность на договорной коммерческой основе за счет клиента (проверяемого субъекта). В организации должна быть создана такая система контроля, которая не только гарантировала бы отсутствие отклонений, ошибок и неэффективности в работе, сколько помогала бы их своевременно выявлять и устранять, способствуя повышению эффективности деятельности. Ведь ресурсы, направленные компанией на создание избыточного контроля, могли бы быть использованы для достижения других целей и задач. Однако даже хорошо выстроенная и организованная система внутреннего контроля нуждается в оценке своей эффективности как с точки зрения достижения поставленных целей, так и с точки зрения экономичности. Этой цели служит внутренний аудит.

Для своевременного и более эффективного внутреннего контроля в организациях используется внутренний аудит. В задачи внутреннего аудита входят создание системы внутреннего контроля, необходимой для осуществления компетенции, прав и ответственности органов управления и должностных лиц, а также четкой системы экономической ответственности должностных лиц и специалистов организации. Внутренний аудит дает аналитическую информацию высшему звену управления организации о её финансово-хозяйственной деятельности, повышает эффективность системы внутреннего контроля и подтверждает достоверность отчетов её обособленных структурных подразделений. Таким образом, функционирование крупных компаний в условиях предпринимательства объективно обусловило создание в аппарате управления службы внутреннего аудита. Международный опыт акционерных обществ США и Западной Европы показывает, что внутренний аудит становится неотъемлемой частью эффективного корпоративного управления.

\begin{abstract}
Analysis of recent studies and publications
Conducting internal audits, the purpose of which is to confirm the reliability of financial statements, identify violations in the financial and economic activities of a legal entity, identify the perpetrators and the reasons that led to errors and formulate recommendations and various proposals that will eliminate the identified violations or minimize risks - this is an activity that is directly related to the functions of the internal control system. Thus, the internal audit is part of the organizational structure of the internal control system.

The internal audit can serve as a mechanism for assessing the effectiveness of the management system "in terms of their organizational and / or technological (i.e. in terms of assessing the set of applied methods, techniques, management technologies, procedures performed) appropriateness."

The effectiveness of the internal audit depends on the adoption and implementation of the necessary decisions for each specific violation in the accounting and tax accounting of the organization, and in turn, the effectiveness of such decisions is determined by the quality of the developed documentation and workflow system, which implies:

- compliance with the rules of rational and timely preparation of documents;

- consistent reflection of all processes of the organization's economic activity;

- rational processing of documents and reducing the path of their passage;

- systematic study and improvement of documents;

- timely execution of relevant decision-making documents and control over their implementation.

Note that the issues of making an inventory of the organization's assets and liabilities (which also refers to
\end{abstract}

internal control measures) are regulated in a separate section of the organization's accounting policy.

The head of the internal audit structure or the designated internal audit professional of the organization should be guided in their activities by:

- legislative and regulatory framework for accounting and reporting, taxation and audit;

- internal documents of the organization "Accounting policy" and "Program of the internal audit (control)".

The document "The accounting policy of the organization" is developed and approved and must comply with the requirements of IFRS. It establishes a set of accounting methods: primary observation, cost measurement, current grouping and final generalization of the facts of economic activity. At the same time, the listed methods include methods of grouping and assessing the facts of economic activity, paying off the value of assets, organizing workflow, inventory, using accounting accounts, preparing accounting registers, processing information.

The internal audit program, in our opinion, should include separate subprograms by type of object (in accordance with the Working Chart of Accounts). Such a program should be developed after approval of the document "Accounting policy of the organization".

In the audit procedure, it is advisable to use special computer programs that allow performing settlement and analytical operations and at the same time assess and predict situations (of the accounting object).

To conduct an internal audit of the accounting object "Stocks - Goods", the auditor must, first of all, familiarize himself with the structure and content of this accounting object.

The structure of accounting objects is presented in the Chart of Accounts. The accounting object "Inventories Goods" is indicated first in section 1 "Short-term assets", subsection 1300 "Inventories", on account 1330 "Goods". 
When conducting an internal audit, it is recommended to follow the Chart of Accounts and the Instructions for its Application, which establish uniform approaches to reflecting the facts of economic activity in the accounting accounts. It should be remembered that the Instruction provides a brief description of synthetic accounts, reveals their structure, purpose, economic content of the generalized facts of economic activity.

\section{Conclusions}

Thus, when conducting an internal audit of Inventories Goods, the auditor must consistently study the structure and content of each sub-account to which the names of the company's goods are assigned. It should be borne in mind that the working chart of accounts formed in each organization is a part (section) of the document "Organization's accounting policy".

As a result of the internal audit of the accounting of materials in the organization, shortcomings in the organization of accounting may be identified, which were prerequisites for developing ways to improve the accounting of materials in order to more efficiently use them and bring them in line with the legislation of the Republic of Kazakhstan.

1. To improve the workflow and the procedure for accounting for settlements with suppliers, the company is recommended to reflect the received inventories in the accounting on the day they actually arrive at the warehouse.

2. To improve the organization of warehouse accounting, it is recommended:

- to establish timely accounting of the receipt and consumption of materials in warehouses;

- timely mark the materials received at the warehouse with individual tags;

- to make the movement of materials by type, instead of the current placement at the time of arrival;
- on inventory cards, indicate information about the location of the material in the warehouse;

- make numbering of shelves and racks in warehouses.

3. For rational accounting of materials, which contributed to operational work, planning and accounting, it is necessary to develop a detailed grouping of materials. For this purpose, the list of names of certain types of stocks is classified according to a certain criterion: they must be divided into groups, which are divided into subgroups. Within each subgroup, in turn, they are grouped by the profile, brand, grade, and then by size, etc.

Each name, grade, section of materials is assigned a permanent cipher (nomenclature number) that uniquely identifies it.

The code (item number) of the material can have the following structure:

Y X XX XXX

where Y characteristic (size, grade);

$\mathrm{X}$ type of material, brand;

XX subgroup of the material;

XXX material group.

The presence of a systematic list of stocks at the enterprise creates the basis for the application of a unified classification in design, technological, planning and accounting documentation, for the mechanization of accounting and computing work, and the use of an operational accounting method for accounting for movement in warehouses.

4. To obtain more objective information about the real cost of inventories, it is advisable for organizations to form reserves for the reduction in the cost of inventories.

5. And also to strengthen the organization and implementation of internal control over inventory accounting, as well as over the organization and maintenance of accounting records, movement of inventories and inventory of material resources.

\section{References}

1. International auditing standards // www.minfin.kz

2. Voronina L.I. Audit: theory and practice // Textbook: In 2 parts Part 2: Practical audit. 4th ed., Rev. and add. M $\therefore$ INFRA M, 2018.344 p.

3. Kazakova N.A. Audit: textbook for academic bachelor's degree under general. ed. N.A. Kazakova. 3rd ed., Rev. and add. Moscow: Yurayt Publishing House, 2018 . 409 p. [in Russian].

4. International Standards on Auditing in Kazakhstan: Textbook. Almaty: Institute of Professional Accountants and Auditors of the Republic of Kazakhstan, 2015. 